\title{
Work Values and Career Aspirations of Women Employees in Government Hospitals in Pangasinan
}

\author{
Merlita Q. Santos, Ed. D. \\ Reynaldo T. Gelido, DPA \\ Pangasinan State University - Lingayen Campus, Philippines
}

\begin{abstract}
This study aimed to determine and analyze the extent of practice of work values and level of career aspirations of women-employees in selected government hospitals in the fifth and sixth congressional districts of Pangasinan, Philippines. The study made use of quantitative and qualitative data and descriptive correlation that looked into the relationship between the extent of practice of work values, level of aspirations and profile characteristics. Sixty nine regular women-employees with different positions were purposively selected. Data were gathered through questionnaire and analyzed using frequency counts and percentage, average weighted mean, Wilk's A and Pearson r. It was found in the study that women-employees a) have ages within the legal age range of government employees; attended trainings/seminars relative to their work; and have monthly income commensurate to their positions; b) always practiced the work values of punctuality, honesty, respect, cooperation and industriousness; and have high level of career aspiration; c) extent of practice of work values and level of career aspiration were comparable across age, civil status, highest educational attainment, position and monthly income' d) encountered problems with varying degrees of seriousness in the practice of work values in their respective work places; e) that significant positive correlation existed between the women-employees' extent of practice of work values and level of career aspiration. Generally, the work values of punctuality, honesty, respect, cooperation and industry practiced by women-employees in the performance of their job have contributed to their high level of career aspiration in their present and future career status.
\end{abstract}

Keywords: Work Values, Career Aspirations, Women Employees, Government Hospitals, Pangasinan

\section{Introduction}

Values are standard which one upholds as desirable and guide one's way of life. Living with good values often gives the bearer a sense of control of his life because he knows what he wants and where to go. Working with values and understanding their importance in one's career enables a person to fit into his profession, clients, colleagues and superiors. Some individuals find satisfaction in their job because it matches their work-related values, while some end up hopping significant to them.

Friendliness, teaching and motivating others, fun, order and harmony decrease stress in the work setting and creates healthier relationships. The rewards and fulfillment financially, morally or spiritually and recognition gives security and stability among the workers. With these characteristics equally valued in the workplace, it promotes efficiency in work. A worker with the right sense of work values is more effective and efficient than one who does not possess the same values (Calderon, 2014).

According to Articula and Florendo (2013), a person with commitment is transparent and open. He is honest, upright, probe and sincere without pretense or deceit. He also manifests loyalty and reliability that he gains the trust and confidence of his superiors, clients and co-workers. Committing one's self to the organization is definitely committing one's self to the work, staff and customers.

Moreover, people work in groups with different behaviors and social backgrounds. They use appropriate technological tools and techniques to achieve organizational goals and be able to coordinate the work among them. Thus, the human resource is considered the lifeblood of an organization. As the saying goes, that no two individuals are exactly alike, human 
resource in an organization varies in terms of its values, job satisfaction and commitment, in its ability to make decisions, and its performance.

The fifth and sixth congressional districts and community hospitals of Pangasinan has around 135 women employees that composed of the chief of Hospital, Section/Division Chief and down to the heads of offices/department and staff. With their mission to pursue a balanced and environmentally sound economic growth through responsible and equitable management of resources and participative governance, women employees should have unified values to work to meet the needs of every customer that comes in and goes out of the hospital.

Work values such as responsibility, accountability, honesty, respect, competence and consistency maintains the integrity of an institution. The desire for knowledge, advancement, personal growth, challenge, creativity, aesthetics and openness to change and variety takes a working group to a higher level of success. Good leadership, autonomy, decision-making, teamwork, power and authority provide a stronger foundation and strengthen the organization.

However, there are organizations where there are observable negative working attitudes of personnel as they render their services in the workplace. Some of these are disobedience from orders of supervisors, leaving the assigned work undone, idleness, absenteeism and tardiness. Collectively, these negative work values serve as constraints and impediments to higher work productivity and organizational performance.

\section{Materials and Methods}

The study was conducted to determine the extent of practice of work values of women employees in selected government hospitals in the fifth and sixth congressional districts of Pangasinan and their level of career aspiration in the performance of their duties and obligations in their respective workplace.

The descriptive correlational method of research was employed in the study since it described women employees' extent of practice of work values and level of career aspiration. It also looked into the relationship between the two variables.

The study was carried out in six (6) selected hospitals in the fifth and sixth congressional districts of Pangasinan, namely: Asingan Community Hospital, Eastern Pangasinan District Hospital, Manaoag Community Hospital, Pozorubio Community Hospital, Urdaneta District Hospital and Umingan Community Hospital.

A total of 69 women employees with permanent and/or plantilla position / item representing different positions were included in this study.

Prior to the survey proper, approval from the Hospital Administrators was sought before the administration of the questionnaire-interview guide to the respondents.

A guided-response type of questionnaire consisted of four parts which was prepared by the researcher as the data gathering instrument was pre-tested and validated. Part I elicited data on the personal profile of the respondents; Part II contained the indicator-statements which measured the respondents' extent of practice of work values in the workplace; Part III dwelt on the indicator-statements which determined the level of career aspirations of the respondents in terms of present career status and preferred career status; while Part IV consisted of possible problems encountered by the respondents in the practice of their work values.

Frequency counts and percentage distribution were used in determining respondent's profile; while frequency counts, average weighted mean and ranks were employed to determine the degree of seriousness of these problems encountered by the respondents on their practice of work values. To determine the extent of practice of work values and level of career aspiration, frequency counts and summated mean drawn from a 5 point Likert Scale was used.

\section{Results and Discussion}

\section{Respondents' Profile}

A total of 69 women employees with permanent status holding different positions in the six hospitals of Pangasinan were included in the study. The profile of respondents is presented in Tables 1 and 2:

Table 1 Profile of the Selected Respondents, $n=69$ 


\begin{tabular}{lll}
\hline Profile & Frequency & Percentage \\
\hline Age & 7 & \\
30 Years and Below & 5 & 10.1 \\
$31-40$ & 28 & 7.2 \\
$41-50$ & 24 & 40.6 \\
$51-60$ & 5 & 34.8 \\
61 Years and Above & 14 & 7.2 \\
\hline Civil Status & \\
Single & 55 & 20.3 \\
Married & 1 & 79.7 \\
\hline Highest Educational Attainment & \\
BS Undergraduate & 55 & 1.4 \\
BS Graduate & 4 & 79.7 \\
With MA/MS & 9 & 5.8 \\
MA/MS Grad & & 13.0 \\
\hline Position & 9 & \\
Administrative Aide & 8 & 13.0 \\
Administrative Assistant/Officer & 3 & 11.6 \\
Dentist/Dental Aide & 2 & 4.3 \\
Nutritionist/Dieticians & 2 & 2.9 \\
Medical Officer & 26 & 2.9 \\
Nurse & 5 & 37.7 \\
Pharmacist & 2 & 7.2 \\
Midwife & 3 & 2.9 \\
Medical Tech & 9 & 4.3 \\
Others & & 13.0 \\
\hline Monthly Income & 4 & \\
10,000.00 and Below & 37 & 5.8 \\
10,001.00-20,000.00 & 18 & 53.6 \\
20,001.00-30,000.00 & 5 & 26.1 \\
30,001.00-40,000.00 & 4 & 7.2 \\
40,001.00-50,000.00 & 1 & 5.8 \\
Above 50,000.00 & & 1.4 \\
\hline & & \\
\hline
\end{tabular}

It can be gleaned from Table 1 that as to profile age, 28 or $40.6 \%$ of the respondents belonged to age range of $41-50 ; 24$ or $34.8 \%$ fall within the age range of $51-60 ; 7$ or $10.1 \%$ have ages 30 years and below; while 5 or $7.2 \%$ respondents for each of the age range of $31-40$ and 61 and above.

As regards civil status, most of the respondents with 55 or $79.7 \%$ are married; while 14 or $20.3 \%$ are single. Meanwhile, relative to educational attainment, most or 55 or $79.7 \%$ respondents are BS graduates; 9 or $13 \%$ are masteral graduates; 4 or $5.8 \%$ have earned masteral units; while 1 or $1.4 \%$ is BS undergraduate. Regarding position, 26 or $37.7 \%$ are nurses; 9 or $12 \%$ are holding administrative aide positions; 8 or $11.6 \%$ are administrative assistant officers; 5 or $7.2 \%$ are pharmacists; 3 or $4.3 \%$ for each of dentist / dental aides and medical technologists; 2 or $2.9 \%$ for each of nutritionists / dieticians, medical officers and midwives; and 9 or $13 \%$ respondents whose positions are not specified and considered occupying other positions.

With respect to monthly income, 37 or $53.6 \%$ belonged to income bracket of Php10,001.00 - Php20,000.00; 18 or $26.1 \%$ with income range of Php20,001.00 - Php30,000.00; 5 or 7.2\% belonged to income range Php40,001.00 - Php50,000.00; 4 or $5.8 \%$ for each of the income brackets of Php10,000.00 and below and Php40,001.00 - Php50,000.00, while only 1 or $1.4 \%$ has an income of P50,000.00 above.

In terms of number of seminars/trainings attended, 14 or $20.3 \%$ respondents have attended 5 or more local trainings/seminars; 6 or $8.7 \%$ - regional and 5 or $7.2 \%$ - national. Three or $4.3 \%$ respondents have attended $1-5$ seminars/trainings in the international level; 24 or $34.8 \%$ - national level; 31 or $44.9 \%$ - regional level and 42 or $60.9 \%$ in the local level. Meanwhile, there are women employees who have not attended any seminars/trainings conducted at the local $-\mathrm{v} 13$ or $18.8 \%$; regional -32 or $46.4 \%$; or national -40 or $58 \%$. 
Table 2 Number of Seminars/Trainings Attended Relevant to the Position, $n=69$

\begin{tabular}{|c|c|c|c|c|c|c|}
\hline \multirow[t]{3}{*}{ Type } & \multicolumn{6}{|c|}{ Number of Seminars/Trainings Attended } \\
\hline & \multicolumn{2}{|c|}{ None } & \multicolumn{2}{|c|}{$1-5$} & \multicolumn{2}{|c|}{5 or More } \\
\hline & $f$ & $\%$ & $f$ & $\%$ & $f$ & $\%$ \\
\hline Local & 13 & 18.8 & 42 & 60.9 & 14 & 20.3 \\
\hline Regional & 32 & 46.4 & 31 & 44.9 & 6 & 8.7 \\
\hline National & 40 & 58.0 & 24 & 34.8 & 5 & 7.2 \\
\hline International & 66 & 95.7 & 3 & 4.3 & 0 & 0.00 \\
\hline
\end{tabular}

\section{Extent of Practice of Women Employees on Work Values}

The distribution of respondents according to their extent of practice of work values with the corresponding mean ratings of their responses on the different indicator-statements of each of the domains of punctuality, honesty, respect, cooperation and industry are reflected in Table 3.

Table 3 Extent of Practice of Work Values of Women-Employees, $n=69$

\begin{tabular}{|c|c|c|c|c|c|}
\hline Work Values & AP & $\mathrm{OP}$ & MP & SP & VSP \\
\hline \multicolumn{6}{|l|}{ A. Punctuality } \\
\hline Report to work on time. & 40 & 26 & 3 & 0 & 0 \\
\hline Attend flag ceremony every Monday. & 43 & 17 & 8 & 1 & 0 \\
\hline $\begin{array}{l}\text { Attend relevant meetings and seminars regularly to improve my skills and knowledge in } \\
\text { hospital works. }\end{array}$ & 45 & 21 & 3 & 0 & 0 \\
\hline Observe work hours, break period, etc & 50 & 15 & 3 & 1 & 0 \\
\hline Submit reports, outputs on or before deadline. & 51 & 15 & 3 & 0 & 0 \\
\hline Average Weighted Mean & \multicolumn{5}{|c|}{ 4.59(Always Practiced) } \\
\hline \multicolumn{6}{|l|}{ B. Honesty } \\
\hline $\begin{array}{l}\text { Accomplish my DTR daily indicating the actual time of arrival and departure from } \\
\text { hospital. }\end{array}$ & 52 & 15 & 1 & 1 & 0 \\
\hline Admit mistakes I commit. & 51 & 14 & 3 & 1 & 0 \\
\hline Accept for my own actions and not blame others. & 54 & 12 & 2 & 1 & 0 \\
\hline Return any belongings left by clients or co-workers in the hospital. & 59 & 9 & 1 & 0 & 0 \\
\hline Render my services with dedication, commitment and sincerity. & 58 & 9 & 2 & 0 & 0 \\
\hline Average Weighted Mean & \multicolumn{5}{|c|}{ 4.75(Always Practiced) } \\
\hline \multicolumn{6}{|l|}{ C. Respect } \\
\hline Greet with courtesy with clients, visitors and co-worker. & 55 & 13 & 1 & 0 & 0 \\
\hline Speak modulated voice. & 41 & 25 & 3 & 0 & 0 \\
\hline Answer honesty and promptly. & 46 & 22 & 1 & 0 & 0 \\
\hline Do not utter unsavory words. & 40 & 26 & 2 & 1 & 0 \\
\hline Control my temper. & 39 & 24 & 6 & 0 & 0 \\
\hline Average Weighted Mean & \multicolumn{5}{|c|}{ 4.60(Always Practiced) } \\
\hline \multicolumn{6}{|l|}{ D. Cooperation } \\
\hline Strive to work cooperatively with my co-worker regardless of their status. & 53 & 13 & 3 & 0 & 0 \\
\hline Try to inspire co-worker to bring quality output. & 48 & 17 & 4 & 0 & 0 \\
\hline Share knowledge/skills with co-worker. & 46 & 19 & 4 & 0 & 0 \\
\hline Try to considerate/fair I dealing with co-worker and clients. & 44 & 23 & 2 & 0 & 0 \\
\hline Strive to show concern for co-worker and clients. & 49 & 16 & 4 & 0 & 0 \\
\hline Average Weighted Mean & \multicolumn{5}{|c|}{ 4.65(Always Practiced) } \\
\hline \multicolumn{6}{|l|}{ E. Industry } \\
\hline Complete work assignment in a more efficient manner. & 44 & 21 & 4 & 0 & 0 \\
\hline Comply work assignment within a target time even without supervision. & 44 & 21 & 4 & 0 & 0 \\
\hline
\end{tabular}


Can render extra time for exigency of service.

Voluntarily participate actively to socio-cultural, spiritual activities and others.

Am very willing to assist clients and co-worker in their needs.

Average Weighted Mean

$\begin{array}{lllll}47 & 18 & 4 & 0 & 0\end{array}$

Overall Weighted Mean

$\begin{array}{lllll}34 & 29 & 6 & 0 & 0\end{array}$

$\begin{array}{lllll}42 & 21 & 6 & 0 & 0\end{array}$

4.54(Always Practiced)

Note: Highest frequencies are in boldface; $\mathrm{DE}=$ Descriptive Equivalent

Legend: 1.00 - 1.80 VSP - Very Seldom Practiced; 1.81 - 2.60 SP - Seldom Practiced; 2.61 - 3.40 MP - Moderately Practiced; 3.41 - 4.20 OP - Often Practiced; 4.21 - 5.00 AP - Always Practiced

Table 3 presents that generally, the women-employees in the different government hospitals always practice the work value of punctuality in their respective work places as evidenced by the overall average weighted mean of 4.59 .

Particularly, the five indicator-statements of punctuality were always practice by the respondents, however, indicator on submitting reports, outputs on or before deadline, and observing work hours, break period, etc. were always practice by most or 50-51 respondents.

On the work value of honesty, Table 3 discloses that in particular most of the women employees always practice honesty in returning any belongings left by clients or co-workers in the hospital with 59 or $86 \%$ respondents practicing it; 58 or $84 \%$ is rendering services with dedication, commitment and sincerity; 54 or $78 \%$ in accepting their own actions and not blaming others; 52 or $75 \%$ in accomplishing DTR by indicating their actual time of arrival and departure from hospital; 51 or $74 \%$ in admitting mistakes that they commit.

Generally, the women employees in the different government hospitals always practice honesty in their respective work places with an average weighted mean of 4.75 .

In terms of respect as one of the domains of work values, Table 3 shows that in particular, most of the women employees always practice respect in their work places by greeting with courtesy clients, visitors and co-workers (55 or $80 \%)$; by speaking in modulated voice ( 41 or $59 \%$ ); by answering honesty and promptly (46 or $67 \%$ ); by not uttering unsavory words ( 40 or $58 \%$ ) and by controlling their temper ( 39 or $57 \%$ )

Overall, the women-employees in the selected government hospitals always practice showing respect to their clients, visitors and co-workers as indicated by the average weighted mean of 4.60 .

With regards to cooperation as a work value, on the whole, the women-employees in the selected government hospitals always practice cooperation in their respective work places as revealed by the general average weighted mean of 4.65.

Particularly, 53 or $77 \%$ respondents always practice cooperation in striving to work cooperatively with their co-workers regardless of their status; 49 or $71 \%$ in striving to show concern for their co-workers and clients; 48 or $70 \%$ in sharing knowledge/skills with their co-workers; 44 or $64 \%$ in trying to be considerate and fair in dealing with co-workers and clients.

On the work value of industry, Table 3 reveals that generally the women-employees in the different government hospitals always practice their work values of cooperation as indicated by the average weighted mean of 4.54.

In particular, 47 or $68 \%$ respondents always practice industry in rendering extra time for exigency of service; 44 or $64 \%$ in complying work assignment within a target time even without supervision and in being willing to assist their clients or co-workers in their needs; while 34 or $49 \%$ in voluntarily and actively participating in socio-cultural, spiritual and other activities.

To sum it all, the overall weighted mean of 4.63 may imply that the women-employees in the selected government hospitals in Pangasinan always practice the different work values in the performance of their duties and obligations in their respective work places.

\section{Level of Career Aspiration of the Women-Employees}

Career aspiration which refers to the present and preferred aspirations of women-employees in terms of their career expectations while working in the government hospitals are reflective of their motivation, satisfaction, expectations regarding conditions of their work and work environment in relation to their present and future career status. 
The distribution of the respondents according to their responses in each of the indicators on career aspiration with the corresponding average weighted mean and overall weighted mean are reflected in Table 4.

Table 4 Level of Career Aspiration of the Women-Employees, $n=69$

\begin{tabular}{|c|c|c|c|c|c|}
\hline Career Aspiration & VHA & $\mathrm{HA}$ & $\mathrm{MA}$ & LOA & LeA \\
\hline \multicolumn{6}{|l|}{ A. Present Career Status } \\
\hline $\begin{array}{l}\text { Current work suits parents, family's idea of success } \\
\text { and I will stay in this job. }\end{array}$ & 21 & 35 & 8 & 2 & 3 \\
\hline $\begin{array}{l}\text { Ability to render service and be significant help and } \\
\text { assistance to sick people with commitment. }\end{array}$ & 28 & 27 & 9 & 1 & 4 \\
\hline $\begin{array}{l}\text { Work provides freedom from very strict supervision } \\
\text { and Organization culture promotes conduciveness } \\
\text { of work environment and healthy work condition. }\end{array}$ & 13 & 40 & 11 & 3 & 2 \\
\hline $\begin{array}{l}\text { Work family that conveys/manifest mutual respect } \\
\text { cooperation and I am satisfied to this present job. } \\
\text { Supportive supervisors who lead with sufficient }\end{array}$ & 19 & 33 & 10 & 5 & 2 \\
\hline $\begin{array}{l}\text { support, motivation, inspiration and I feel the } \\
\text { contentment in this job. }\end{array}$ & 23 & 28 & 13 & 4 & 1 \\
\hline Average Weighted Mean & \multicolumn{5}{|c|}{$\begin{array}{l}3.96 \\
\text { (High Level of Aspiration) }\end{array}$} \\
\hline \multicolumn{6}{|l|}{ B. Future Career Status } \\
\hline $\begin{array}{l}\text { Career in the hospital world represent progress } \\
\text { through increased recognition on salary. }\end{array}$ & 15 & 25 & 24 & 4 & 1 \\
\hline $\begin{array}{l}\text { Complete/earn, masters/doctorate degree to secure } \\
\text { promotion in the work place. }\end{array}$ & 10 & 31 & 23 & 3 & 2 \\
\hline $\begin{array}{l}\text { Occupation to continue having the prestige } \\
\text { especially for women as employees in the hospital. }\end{array}$ & 13 & 37 & 14 & 3 & 2 \\
\hline $\begin{array}{l}\text { Higher prospect for lo9ng term security in the } \\
\text { hospital service. }\end{array}$ & 18 & 32 & 13 & 3 & 3 \\
\hline $\begin{array}{l}\text { Given continuous recognition and incentives or } \\
\text { rewards for an excellent job and more teambuilding } \\
\text { and general Wellness activities be conducted } \\
\text { among the hospital employees. }\end{array}$ & 16 & 26 & 21 & 4 & 2 \\
\hline Average Weighted Mean & \multicolumn{5}{|c|}{$\begin{array}{l}3.75 \\
\text { (High Level of Aspiration) }\end{array}$} \\
\hline Overall Weighted Mean & \multicolumn{5}{|c|}{$\begin{array}{l}3.86 \\
\text { (High Level of Aspiration) }\end{array}$} \\
\hline
\end{tabular}

Note: Highest frequencies are in boldface; $\mathrm{DE}=$ Descriptive Equivalent

Legend: 1.00 - 1.80 LeA - Least Level of Aspiration; 1.81 - 2.60 LoA - Low Level of Aspiration; 2.61 - 3.40 MA Moderate Level of Aspiration; 3.41 - 4.20 HA - High Level of Aspiration; 4.21 - 5.00 AP - Very High Level of Aspiration

\section{Level of Career Aspiration in Present Career Status}

Table 4 shows that along present career status, 28 or $41 \%$ respondents have very high level of career aspiration when they have the ability to render service and be of significant help and assistance to sick people with commitment; 40 or $58 \%$ have high level of career aspiration when their current work provides freedom from very strict supervision and organization culture which promotes conduciveness of work environment and healthy work condition; 35 or $51 \%$ with high level of career aspiration when their work suits parents, family's idea of success and they will stay in the job.

On the whole, the women-employees of the selected government hospitals in Pangasinan have high level of career aspiration in their present career status as indicated in the average weighted mean of 3.96 .

\section{Level of Career Aspiration in Future Career Status}

It is shown in Table 4, page 5 the distribution of respondents according to their level of career aspiration in each of the expectations regarding the conditions of their work and work environment along their future career status. 
Table 4 reveals that respondents claimed that they have high level of career aspiration given each of the conditions where occupation to continue having the prestige especially for women as employees in the hospital, (37 or $53.62 \%$ ); higher prospect for long term security in the hospital service, (32 or $46.38 \%$ ); complete/earn masteral/doctoral degrees to secure promotion in the workplace, (31 or $44.93 \%$ ); career in the hospital would represent progress through increased recognition on salary (25 or $36.23 \%)$; and given continuous recognition and incentives or rewards for an excellent job and more team building and general wellness activities conducted among the hospital employees (26 or $37.68 \%$ )

Generally, the women-employees in the selected government hospitals have high level of career aspiration in their future career status as reflected in the average weighted mean of 3.75 .

In a summary, the overall weighted mean of 3.86 signifies high level of career aspiration of the women-employees in the selected government hospitals in Pangasinan.

\section{Problems Encountered By Women-Employees in the Practice of Work Values in their Jobs}

The distribution of respondents according to the degree of seriousness of the problems they have encountered together with the average weighted means and ranks of the problems are indicated in Table 5.

Table 5 Problems Encountered By Women-Employees in the Practice of Work Values in Their Jobs, $n=69$

\begin{tabular}{|c|c|c|c|c|c|c|c|}
\hline Possible Problems & VS & $S$ & MoS & $\mathrm{MaS}$ & NP & AWM & RANK \\
\hline $\begin{array}{l}\text { Delayed action to request for repair of } \\
\text { facilities and equipment. }\end{array}$ & 10 & 25 & 24 & 8 & 2 & 3.48 & 1 \\
\hline $\begin{array}{l}\text { Delay in the requisitioning of supplies and } \\
\text { materials. }\end{array}$ & 9 & 23 & 26 & 10 & 1 & 3.42 & 2 \\
\hline Extra duties due to lack of manpower. & 17 & 17 & 17 & 8 & 10 & 3.33 & 3 \\
\hline $\begin{array}{l}\text { No scholarship program for employees to } \\
\text { pursue further studies. }\end{array}$ & 11 & 18 & 25 & 5 & 10 & 3.22 & 4 \\
\hline $\begin{array}{l}\text { No special benefits or considerations given } \\
\text { compensation overtime or extra duties. }\end{array}$ & 14 & 13 & 25 & 4 & 13 & 3.16 & 5 \\
\hline Irregularity of other monetary benefits. & 9 & 18 & 22 & 10 & 10 & 3.09 & 6 \\
\hline Favoritism in the organization. & 10 & 16 & 23 & 9 & 11 & 3.07 & 7 \\
\hline $\begin{array}{l}\text { Only few or the same persons are given } \\
\text { chance to attend trainings. }\end{array}$ & 7 & 19 & 22 & 11 & 10 & 3.03 & 8 \\
\hline Fast turn-over of personnel. & 8 & 20 & 16 & 13 & 12 & 2.99 & 9 \\
\hline Delay of salary. & 7 & 18 & 22 & 10 & 12 & 2.97 & 10 \\
\hline
\end{tabular}

Note: Highest frequencies are in boldface; DE=Descriptive Equivalent, $A W M=$ Averaged Weighted Mean

Legend: 1.00 - 1.80 NP - Not a Problem; 1.81 - 2.60 MaS - Marginally Serious; 2.61 - 3.40 MoS - Moderately Serious; 3.41 - 4.20 S - Serious; 4.21 - 5.00 VS - Very Serious

It can be noted in Table 5 that there are 10 problems identified by the respondents in the practice of work values in their respective jobs.

Among the top three which were considered serious problems by the women-employees as evidenced by their average weighted mean and rank are: "Delayed action to request for repair of facilities and equipment", (AWM - 3.48, Rank 1); "Delay in the requisitioning of supplies and materials", (AWM - 3.42, Rank 2); and "Extra duties due to lack of manpower", (AWM - 3.33, Rank 3).

Other problems that they have encountered in the practice of work values in their jobs were considered as moderately serious. 


\section{Significant Difference on the Extent of Practice of Work Values of Women-Employees}

\section{Across Profile Variables}

The results of data analysis using Wilk's $A$ on the significance of the differences between the extent of practice of work values of women-employees in their jobs across profile variables are presented in Table 6.

It can be deduced from the results that no significant difference exists on the extent of practice of women employees on work values across profile variables. The obtained multivariate Wilk's A values of all the profile variables range from .490 to .849 with significance levels ranging from .051 to .487 which are all greater than the .05 level of significance.

These findings may imply that regardless of their age, civil status, highest educational attainment, position and income, their extent of practice of the work values on their jobs are comparable. These findings may also reinforce the previous results on their extent of practice that generally, women-employees always practice the work values of punctuality, honesty, respect, cooperation and industry.

Table 6 Significant Difference in the Extent of Practice of Work Values of Women-Employees Across Profile Variables

\begin{tabular}{lll}
\hline Profile & Wilk's $\Lambda$ & Sig. \\
\hline Age & $.490^{\mathrm{ns}}$ & .051 \\
Civil Status & $.794^{\mathrm{ns}}$ & .081 \\
Highest Educational Attainmenta & $.723^{\mathrm{ns}}$ & .176 \\
& & \\
Position & $.742^{\mathrm{ns}}$ & .233 \\
Monthly Income & .348 \\
Seminar Attended & $.608^{\mathrm{ns}}$ & \\
Local & & .487 \\
Regional & $.802^{\mathrm{ns}}$ & .087 \\
National & $.681^{\mathrm{ns}}$ & .269 \\
International & $.752^{\mathrm{ns}}$ & .225 \\
\hline
\end{tabular}

Note: " ns Not Significant, aSome categories were collapsed due to minimum number of cases.

\section{Significant Difference on the Level of Career Aspiration of Women Employees}

\section{Across Profile Variables}

This section discusses the significance of the differences in the career level of aspiration of the women employees across profile variables. The obtained multivariate Wilk's A values together with their corresponding level of significance are presented in Table 7.

Table 7 Significant Difference of Women Employees' Level of Career Aspirations Across Their Profile Variables

\begin{tabular}{lll}
\hline Profile & Wilk's $\Lambda$ & Sig. \\
\hline Age & $.811^{\mathrm{ns}}$ & .302 \\
Civil Status & $.998^{\mathrm{ns}}$ & .958 \\
Highest Educational Attainmenta & $.850^{\mathrm{ns}}$ & .123 \\
Position & $.927^{\mathrm{ns}}$ & .496 \\
Monthly Income & $.888^{\mathrm{ns}}$ & .713 \\
Seminar Attended & & \\
Local & $.960^{\mathrm{ns}}$ & .768 \\
Regional & $.974^{\mathrm{ns}}$ & .881 \\
National & $.991^{\mathrm{ns}}$ & .984 \\
International & $.973^{\mathrm{ns}}$ & .550 \\
\hline
\end{tabular}

Note: nsNot Significant, aSome categories were collapsed due to minimum number of cases. 
It can be inferred from the results that no significant differences exists in the level of career aspiration across profile characteristics of the women employees in the selected government hospitals in the province of Pangasinan as revealed by the multivariate Wilk's A values which range from .811 to .998 with corresponding significance levels ranging from .123 to .984 which are all greater than the .05 level of significance. Thus, it can be deduced that the level of career aspiration of women employees in the selected government hospitals are the same across profile characteristics. These findings may imply that the profile characteristics of the women employees such as age, civil status, highest educational attainment, position, monthly income and seminars attended do not cause any variation or have not affected their level of career aspiration.

\section{Relationship Between the Women Employees' Extent of Practice of Work Values on their Job and Level of Career Aspiration}

This portion of the study discusses the relationship between the extent of practice of work values and level of career aspiration of women employees in the selected government hospitals in the province of Pangasinan. The obtained coefficients of correlation with the corresponding level of significance are indicated in Table 7.

Table 8 Coefficients of Correlation Between Extent of Practice of Work Values and Level of Career Aspiration of Women employees

\begin{tabular}{|c|c|c|c|c|c|c|}
\hline \multirow{3}{*}{$\begin{array}{l}\text { Extent of Practice of } \\
\text { Work Values }\end{array}$} & \multicolumn{6}{|c|}{ Level of Career Aspiration } \\
\hline & \multicolumn{2}{|c|}{ Present Career Status } & \multicolumn{2}{|c|}{ Future Career Status } & \multicolumn{2}{|c|}{ Overall Level of Aspiration } \\
\hline & $r$ & Sig. & $r$ & Sig. & r & Sig. \\
\hline Punctuality & $.358^{* *}$ & .002 & $.363^{* *}$ & .000 & $.360^{* *}$ & .000 \\
\hline Honesty & $.430 * *$ & .000 & $.398 * *$ & .000 & $.422^{* *}$ & .000 \\
\hline Respect & $.330^{* *}$ & .008 & $.345^{\star *}$ & .003 & $.339^{* *}$ & .004 \\
\hline Cooperation & .420 ** & .000 & $.448^{* *}$ & .000 & $.426^{* *}$ & .000 \\
\hline Industry & $.380^{* *}$ & .001 & $.362^{* *}$ & .006 & $.365^{\star *}$ & .002 \\
\hline $\begin{array}{l}\text { Overall Extent of } \\
\text { Practice }\end{array}$ & $.354^{\star *}$ & .002 & $.349^{* *}$ & .006 & $.346^{* *}$ & .008 \\
\hline
\end{tabular}

It can be deduced from the obtained coefficients of correlation the women employees' extent of practice of work values related to punctuality, honesty, respect, cooperation and industry as well as their overall extent of practice of work values are significantly related to their level of career aspiration in the present career status and future career status as well as their overall level of career aspiration as clearly shown by the obtained coefficients of correlation ranging from .330 to .448 with corresponding significance level that are all less than the .01 level of significance. These imply that the hypothesis of no relationship between the two variables is rejected. The significant positive correlation indicates that the greater the extent of practice of work values by the women employees in the selected government hospitals in the province of Pangasinan, the higher is their level of career aspiration in their present career status, future career status as well as their overall level of career aspiration.

\section{Conclusions}

In conclusion, the women employees in the fifth and sixth congressional district s of Pangasinan always practice the work values related to the performance of their jobs in relation to punctuality, honesty, respect, cooperation and industry. They have high level of aspiration related to their present career status and future career status. Moreover, the women employees' profile of age, civil status, highest educational attainment, position and monthly income has not influence the extent of practice of work values in their respective jobs and their present career status and future career status. Further, the significant positive correlation suggests that the greater the extent of practice of work values by the women employees , the higher is the level of their career aspiration in their present and future career status. The women employees encounter problems of various degree of seriousness in the practice of work values in the performance of their respective jobs. 


\section{Referrences}

\section{Books}

[1] Andres, Tomas D. (2011) . Understanding Filipino Values: A Management Approach. pp. 46-53. Tomas D.Andres and New Day Publishers. Quezon City, Philippines.

[2] Andres, Tomas D. (2010). Management of Filipino Values: A Sequel to Understanding Filipino Values. pp. 58-59 Tomas D. Andres and New Day Publishers. Quezon City, Philippines.

[3] Andres, Tomas D. and Pilar B. Andres. (2008) Understanding the Filipino. pp. 54-59. Tomas D.Andres and New Day Publishers. Quezon City, Philippines.

[4] Articulo, Archimedez C. and Gloria G. Florendo. (2010). Values and Work Ethics

[5] Kahayon, Alicia and Gaudencio Aquino. (1995). General Psychology (3rd edition)

[6] Means, R.L. (1970). The Ethical Imperative: The Crisis in American Values. p. 56. Garden City New York: Doubleday \& Company, Inc. Pagoso, C.M. and R.A Montana. Introductory Statistics. REX Bookstore, Manila, Philippines. 1985.

[7] Ramirez, Luzviminda F. and Eden T. Beltran. (2004). Man, Values and Work Ethics,

\section{[8] Unpublished Materials}

[9] Gazmen, A.R. (2008). Work Values among Administrative Personnel of Region I Medical Center.MDM Thesis. PSU-Open University System, Lingayen, Pangasinan.

[10] Rivera, John C. (1998). Perceived Effectiveness of the Values Orientation Workshop (VOW) Program of the Civil Service Commission in Region I. Masteral Thesis.Pangasinan State University, Graduate School, Urdaneta City,

[11] Ancheta, M.A. (1995.) Work Values of Local Employees in Pozurobio, Pangasinan (Unpublished Masteral Thesis) Luzon Colleges, Dagupan City.

[12] Coloma, Cristina B. (1986) Researcher's Perceptions of their Job Climate, implication to Personnel Administration. Unpublished Master's Thesis. Mariano Marcos State University, Agoo, La Union

[13] Lam, Ligaya R. (1992). Local Government Policies and Practices in Hiring and Compensation at Caloocan City: A Critical Analysis. Unpublished Master's Thesis. Gregorio AranetaUniversity, Manila

[14] Mendoza, M. (1986). Work Values Profile of Baguio City Teachers. (Unpublished Dissertation) Saint Louis University, Baguio City

[15] Nabua, E.F. (1990). Factors Affecting Job Satisfaction and Works Values of Primary School Teachers in Petchabun, Thailand (Unpublished Dissertation) CLSU, Nueva Ecija

[16] Simeon, S.P. (1995). Work Values: Organizational Climate and Job Satisfaction of the Employees of the Department of public works and Highways in Region I.Unpublished Master Thesis. Mariano Marcos State University, Laoag City.

[17] Viloria, M. A. (1993). Work Environment Perceptions of the Personnel of a University: Implications to Human Resources Performance. Unpublished Master's Thesis Mariano Marcos University, Laoag City

[18] Yanson, Q. (1982). Factors Among Faculty Members of lloilo State Colleges of Fisheries (Unpublished Master's Thesis) West Visayas State College, lloilo City.

[19] Internet

[20] Culture and Values. http://www.healthcareworkforce.org/healthcareworkforce app/jsp/cellist.jsp?programfocus $=4$

[21] Encarta Premium Suite (2005).

[22] Microsoft Encarta Encyclopedia Deluxe, 2004

[23] Reamer, Frederic G. Ethics and Values. http://home.insight.rr.com/schwertfager/ Documents/ Ethics\%20and20Values.htm, 2004

[24] What are you current work Values? http://www.csd.uwa.edu.au/job/guide/ex_3.htm

[25] Work Values Checklist. http://midcareer.com/articles/careerdevelopment/values 